\title{
Endurgerð meðferðar frá Austur-Evrópu
}
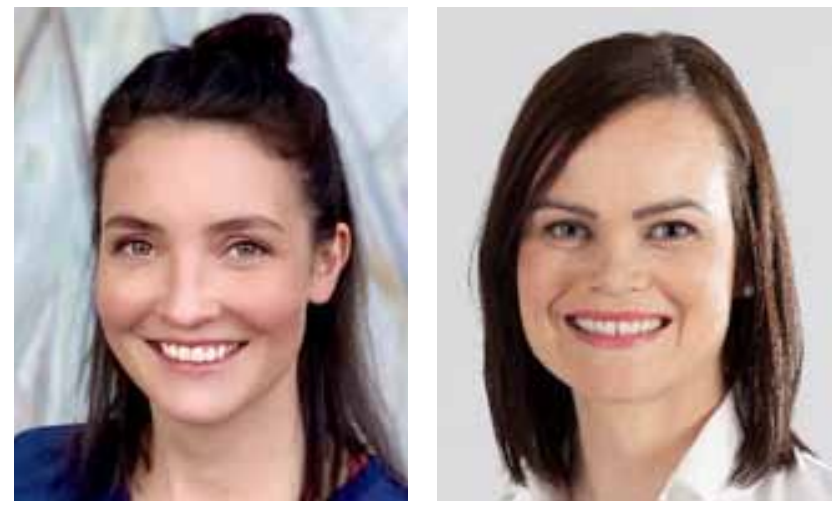

CAMILLA PETRA SIGURĐARDÓTTIR, CAND. ODONT.

ERNA RÚN EINARSDÓTTIR, CAND.ODONT. MS

LEKTOR Í TANN- OG MUNNGERVAL/EKNINGUM, TANNL/EKNADEILD HÁSKÓLA ÍSLANDS

NETFÖNG: camillapsig@gmail.com, ere@hi.is TANNLÆKNABLAĐIĐ 2020; 38: 40-45

doi: 10.33112/tann.38.1.4

\section{ÁGRIP}

Grein pessi lýsir sjúklingatilfelli frá Háskóla Íslands, einstaklingurinn fór til Austur-Evrópu og smíðað var á allar tennur árið 2011, viku eftir ísetningu datt fyrsta krónan. Pegar sjúklingurinn kom í skoðun við Tannlæknadeild Hí hafði hann kul og verki víða. Tannskurður var lagaður til, fyllingum skipt út, viðeigandi tennur rótfylltar, plantar settir í tannlaus bil og bithæð stillt af í bráðabirgðalausn. Smíðuð voru ný tanngervi í réttri bithæð. Við endurgerð meðferðar öðlaðist sjúklingurinn eðlilega tyggigetu og útlit tanna, einnig losnaði hann við verki og kul sem fylgja berum tannskurðum.

Lykilorð: Krónu- og brúargerð, bithækkun, sjögrens, tannátuáhætta, fjaðurbrúnir.

\section{Inngangur}

Verkefnið fjallar um sjúklingatilfelli á Tannlæknadeild Háskóla Íslands. Sjúklingurinn, 51 árs karlmaður, kom í skoðun við Tannlæknadeild Háskóla Íslands haustið 2018 en komst ekki að í meðferð pá. Hann kom aftur í skoðun 13. mars 2019 og fékk tíma í skurðtannlækningum, par sem dregnar voru vonlausar tennur. Hann kom í skoðun í tanngervalækningum í kjölfarið.

Sjúklingurinn hafði farið til Austur-Evrópu árið 2011 og fengið krónur á allar tennur utan 38. Fyrsta krónan datt af viku eftir ísetningu og pegar hann var skoðaður voru einungis 6 krónur eftir í munni (Myndir 1-6, 13 og 18). Hann hafði verki og tannkul víða sem erfitt var að staðsetja, var löngu hættur að brosa og gat illa tuggið.

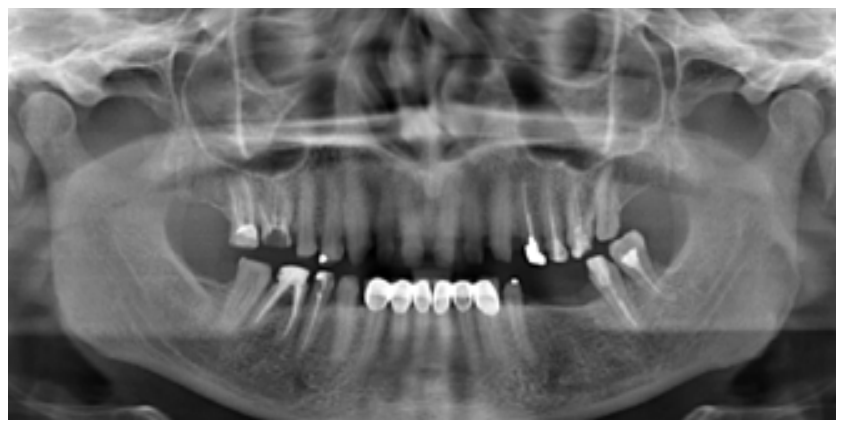

Mynd 1 - Breiðmynd fyrir meðferð 


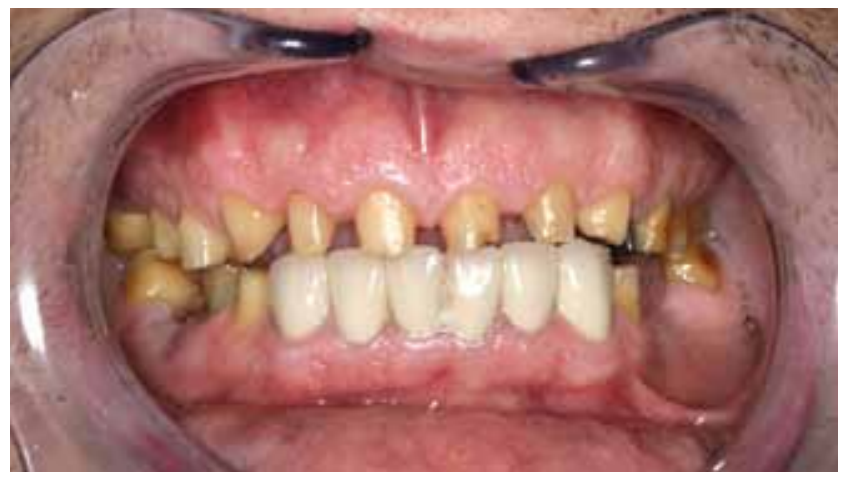

Mynd 2 - Frontal mynd fyrir meðferð

\section{Sjúkrasaga}

Sjúklingurinn er með Sjögren's sjúkdóm, vélindabakflæði, slitgigt, psoriasis-gigt og er nýlega hættur að reykja en hann reykti hálfan pakka á dag. Hann er með ofnæmi fyrir latexi, opíóðum, penicillini og maíssterkju og polir illa deyfingar með adrenalíni að sögn. Hann á erfitt með svefn og tekur Alprazolam Mylan við pví. Við bakflæðinu tekur hann Pariet en önnur lyf tekur hann ekki að staðaldri. Hann hefur farið í skurðaðgerðir vegna klemmdra tauga og er slæmur í baki. Hann fór síðast til tannlæknis fyrir 4-5 árum.

Ástæða pess að velflestar tennur voru krýndar eru ekki að fullu ljósar en saga sjúklings bendir til pess að hann hafi verið með slit á framtönnum.

\section{Skoðun}

Ekkert óeðlilegt kom í ljós við skoðun utan munns, pó mátti greina fremur samfallna andlitshæð.

Í munni mátti sjá tori mandibularis í regio sublingualis í báðum hliðum (Mynd 4). Slímhúðarskoðun var innan eðlilegra marka. Ekki greindist munnvatnsskortur. Við skoðun komu í ljós berir tannskurðir allra tanna utan 38, 33-43. Á framtönnum neðri góms voru til staðar splintaðar málmpostulínskrónur. Klínískt greindist alvarlegt misfitt á brúnum. Við röntgenskoðun kom í ljós tannáta í tönnum 25,26, 16 og 46, einnig var greinanleg umrótarbólga við 38. Tannholdsskoðun var innan eðlilegra marka.

Sjúklingurinn fór í munnvatnspróf haustið 2018 og kom í ljós mjög lág buffervirkni (5), eðlilegt pH-gildi (óörvað 6,4 - örvað 7,4), eðlilegt munnvatnsflæði (óörvað 0,1 ml/ min - örvað $2,9 \mathrm{ml} / \mathrm{min}$ ), lág talning á streptococcus mutans $\left(6,4 \times 10^{4} / \mathrm{ml}\right)$ og há talning á lactobaccilus $\left(>10^{5} / \mathrm{ml}\right)$.

Tvær tennur voru metnar vonlausar, 16 og 46. Tönn 24 var með töluvert breiða stiftisuppbyggingu og tap á tannvef og var pví flokkuð varasöm, vegna aukinnar hættu á rótarbroti. Aðrar tennur voru flokkaðar öruggar (Mynd 7).

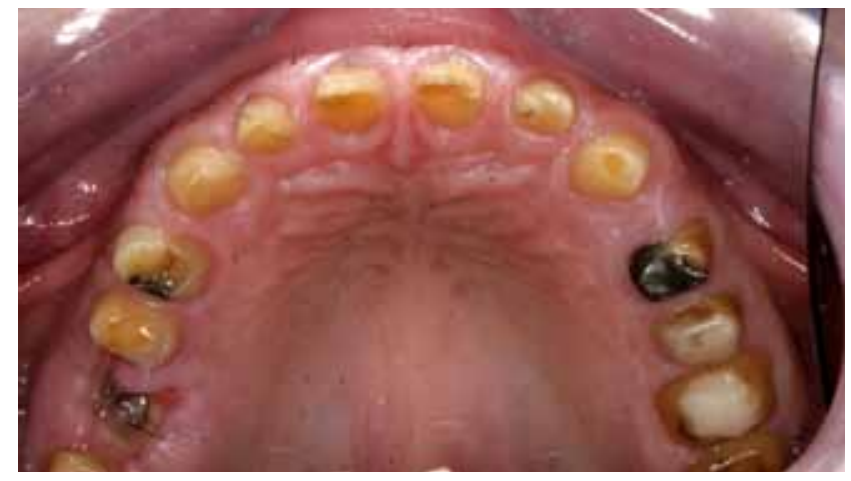

Mynd 3 - Occlusalmynd af efri góm fyrir meðferð

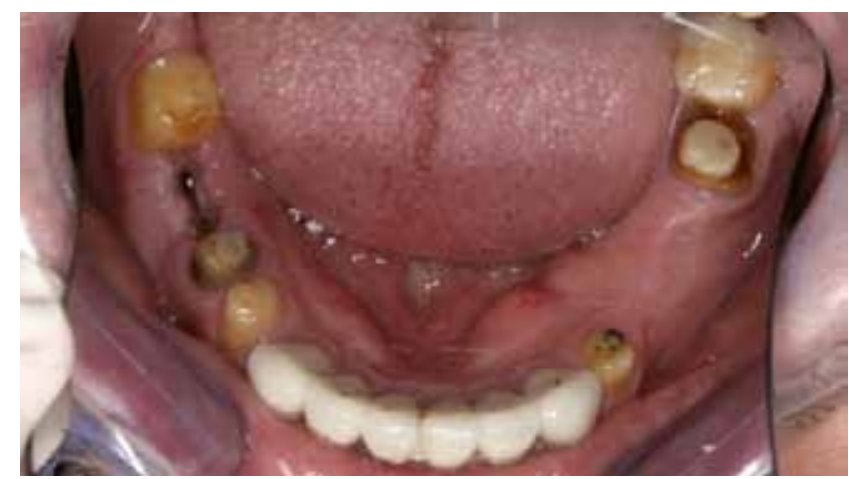

Mynd 4 - Occlusalmynd af neðri góm fyrir meðferð

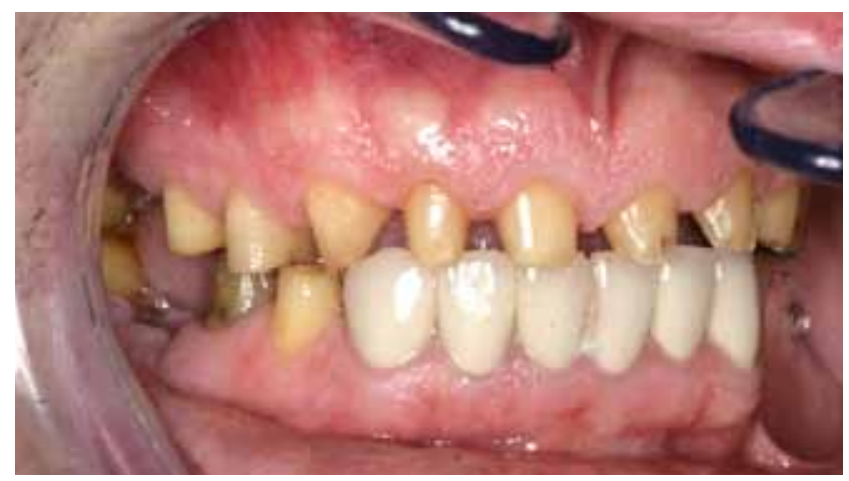

Mynd 5 - Hliðarmynd af hægri hlið fyrir meðferð

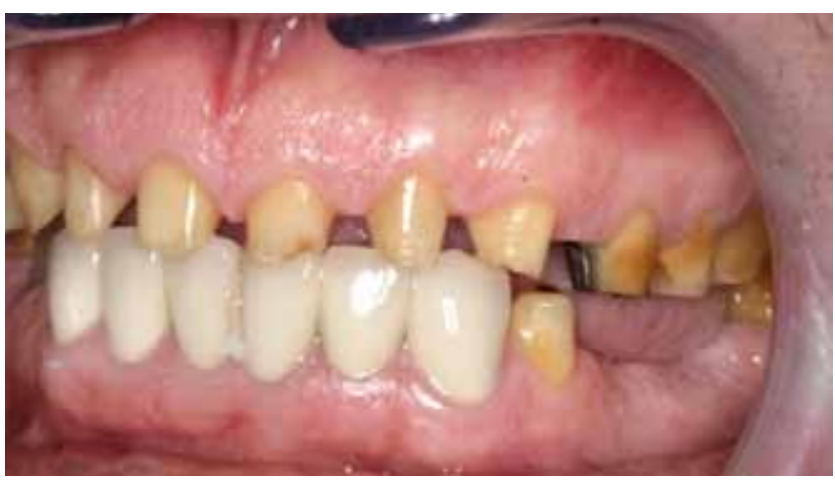

Mynd 6 - Hliðarmynd af vinstri hlið fyrir meðferð 


\section{Greining}

1. Tannleysi: 18, 28, 35, 36 og 48.

2. Tannáta: $16,25,26$ og 46.

3. Krónísk umrótarbólga: 38 .

\section{Orsakavaldar}

Tannsýkla og bakteríur ofan tannholds, óafturkræfar tannvefsskemmdir vegna tannlæknameðferðar (e. iatrogenic damage) erlendis.

\begin{tabular}{|l|l|l|l|l|l|l|l|l|l|l|l|l|l|l|l|l|}
\multicolumn{1}{c|}{18} & 17 & 16 & 15 & 14 & 13 & 12 & 11 & 21 & 22 & 23 & 24 & 25 & 26 & 27 \\
\hline Vonlaus & & & $\mathrm{x}$ & & & & & & & & & & & & & \\
\hline Varasöm & & & & & & & & & & & & $\mathrm{x}$ & & & & \\
\hline Örugg & & $\mathrm{x}$ & & $\mathrm{x}$ & $\mathrm{x}$ & $\mathrm{x}$ & $\mathrm{x}$ & $\mathrm{x}$ & $\mathrm{x}$ & $\mathrm{x}$ & $\mathrm{x}$ & & $\mathrm{x}$ & $\mathrm{x}$ & $\mathrm{x}$ & \\
\hline Örugg & & $\mathrm{x}$ & & $\mathrm{x}$ & $\mathrm{x}$ & $\mathrm{x}$ & $\mathrm{x}$ & $\mathrm{x}$ & $\mathrm{x}$ & $\mathrm{x}$ & $\mathrm{x}$ & $\mathrm{x}$ & & & $\mathrm{x}$ & $\mathrm{x}$ \\
\hline Varasöm & & & & & & & & & & & & & & & & \\
\hline Vonlaus & & & $\mathrm{x}$ & & & & & & & & & & & & & \\
\hline
\end{tabular}

Mynd 7 - Áhættugreining stakra tanna

\section{Meðferðaráætlun}

Heilbrigðisfasi:

Ávísun Duraphat tannkrems (5000 ppm-) gegn tannátu.

Undirbúningsfasi:

Tannhreinsun, fræðsla, kennsla og hvatning í munnhirðu. Úrdráttur á 16 og 46, plastblendisfyllingar í 25 og 26, endurrótfylling 38 og rótfylling 27.

Uppbyggingarfasi:

Plastblendisuppbyggingar í 17, 14, 37, 38 og 45. Tannplantar í stæði 16, 35 og 36, Straumann 4,1 mm x 10 mm BL planti í stæði 16 og Straumann 4,1 mm x 10 mm TL Standard Plus plantar í stæði 35 og 36.

Heilfræstar lithium disilicate krónur með ábrenndu postulíni á 13, 12, 11, 21, 22 og 23, heilfræstar zirconium krónur með ábrenndu postulíni á 17, 15, 14, 24, 25, 26, 27, 37, 34, 33, 32, 31, 41, 42, 43 og 44, heilfræsta zirconium-brú á 45-47 og skrúfaðar, heilfræstar zirconium plantakrónur sem límdar eru utan munns á Straumann Variobase ${ }^{\circledR}$ títan abutment á 16, 36 og 35 (Mynd 10).

Sjúklingur óskaði eftir að hafa diastemu milli 11 og 21, en pannig höfðu hans eigin tennur verið og er pað mikið fjölskyldueinkenni að hans sögn. Einnig ákváðum við að hafa diastemu milli 23 og 24, vegna pess hve mikið bil er á milli pessara tanna.

Viðhaldsfasi:

Mjúk bitskinna útbúin í neðri góm til að vernda smíðina, sem sjúklingi var ráðlagt að nota á nóttunni. Mælt var með reglulegu eftirliti að virkri meðferð lokinni.

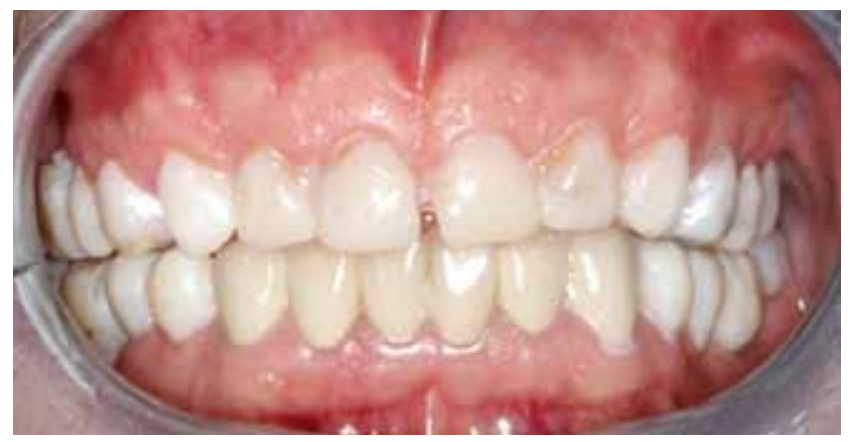

Mynd 8 - Mock-up með 2 mm hækkun

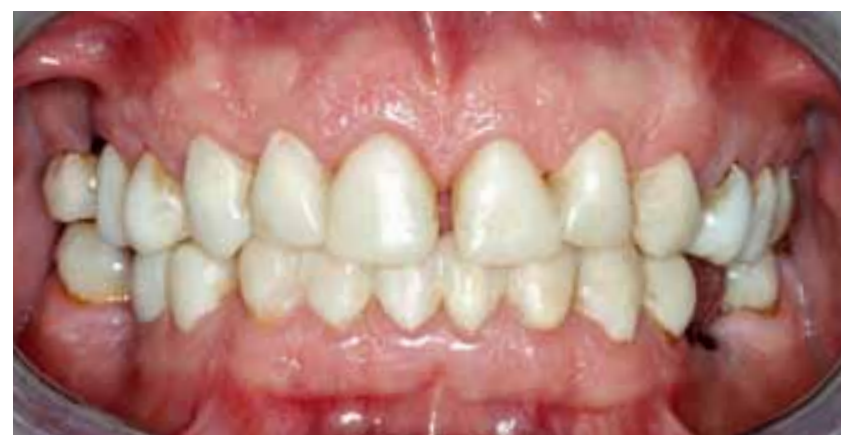

Mynd 9 - Bráðabirgðalausn með 4 mm hækkun

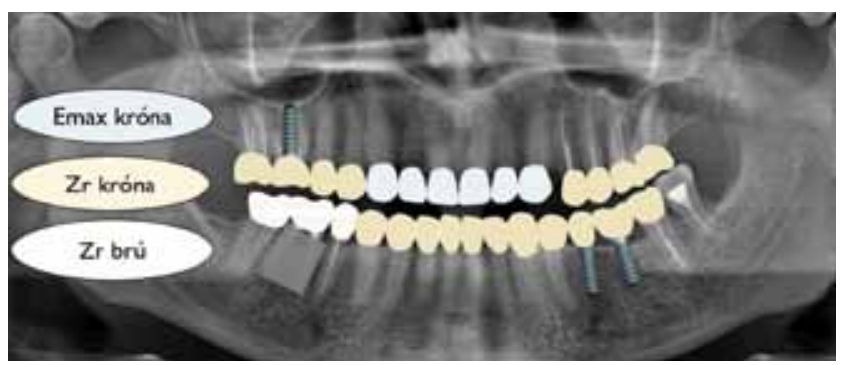

Mynd 10 - Áætluð krónu- og brúargerð

\section{Meðferð}

Vegna verkja í 47 og 26 , var 47 rótfyllt og 26 endurrótfyllt. Að öðru leyti var uppbyggingarfasinn eftir meðferðaráætlun.

Fyrsta uppvöxun (e. mock-up) var gerð með $2 \mathrm{~mm}$ bithækkun í bithermi, hún var mátuð í munni til að meta útlit og hljóðmyndun (Mynd 8). Efri góms tennur voru metnar of stuttar og occlusal rými fyrir jaxlakrónur of lítið. Pví var bithæð í bithermi hækkuð enn um $2 \mathrm{~mm}$ eða alls $4 \mathrm{~mm}$. Hann var með bráðabirgðalausn í peirri bithæð um tíma og gekk vel að venjast. Útlit, tal og tygging var innan eðlilegra marka og sjúklingur var ánægður (Mynd 9).

Ákveðið var að skipta verkefninu i tvö skref, klára efri góms tanngervi fyrst áður en hafist var handa við gerð tanngerva í neðri gómi. Tekið var alginatmát af bráðabirgðalausnum fyrir tannsmið til viðmiðunar sem og ljósmyndir, innan og utan munns. Petta auðveldar tannsmið að átta sig á 
miðlínu, stærð og formi áætlaðra króna. Lokamát var tekið með polyether mátefni. Bitskráning fyrir efri tanngervi var gerð með sjálfhertu plasti (pattern resin) á premur stöðum á móti neðri góms bráðabirgðalausn (Mynd 11). Máttaka og bitskráning fyrir gerð tanngerva í neðri gómi fór fram á sama máta og gerð var fyrir efri góm. Bitskráning var örlítið öðruvísi pví sílikon-bitefni var notað á framtannasvæði (Mynd 12). Allar krónur voru límdar með sjálf- og ljóshertu lími, lithium disilicate krónur voru meðhöndlaðar skv. leiðbeiningum framleiðanda til að hámarka hald. Skrúfaðar lausnir voru gerðar á tannplantakrónur. Skrúfur voru hertar $35 \mathrm{Ncm}$ og fyllt í skrúfgat með PTFE-efni og plastblendi.

Mynd 11 - Samanbit fyrir efri góms smíði
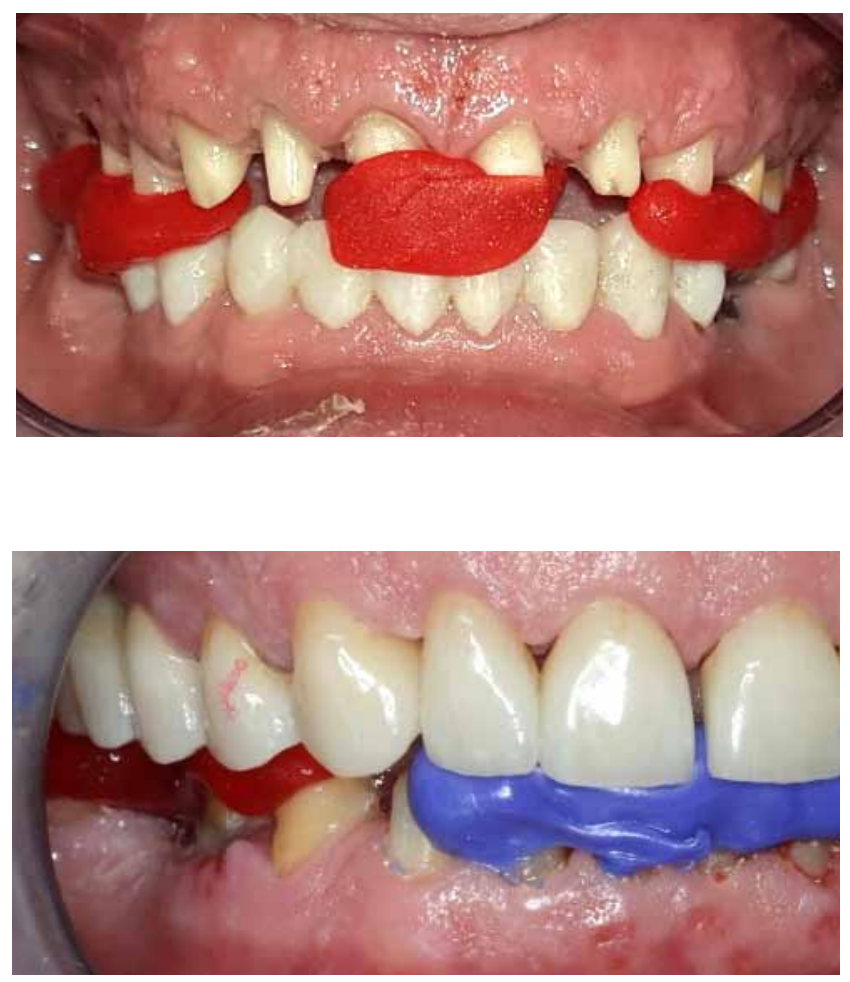

Mynd 12 - Samanbit fyrir neðri góms smíði

Bit var aðlagað lítillega til að tryggja jafnar snertingar í péttasta biti. Framtannastýring í frambiti og hópstýring í hliðarbiti.

\section{Eftirfylgni}

Sjúklingar með Sjögren's eru í sérstökum áhættuhópi vegna tannátu og glerungseyðingar, bæði vegna munnpurrks og síðri gæða munnvatns (1). Prátt fyrir svo umfangsmikla meðferð er mikilvægt að hafa í huga að hún kemur ekki í veg fyrir vandamál í framtíðinni, t.d. tannátu. Pví er grundvallaratriði að gera sjúkling virkan í meðferðinni, fræða hann um orsakir tannvandamála og gera hann að pátttakanda í meðferðarvali með pví að ræða kosti, galla og takmarkanir bæði hvað varðar líffræðilega og efnistengda pætti. Gott er að ræða góða eftirfylgd áður en meðferð er hafin, svo sjúklingur verði strax meðvitaður um mikilvægi pess. Sjúklingur er kallaður inn í eftirlit sem er sniðið að hans pörfum, gott er að hafa pétt eftirlit til að byrja með og meta hvernig sjúklingi tekst til að fylgja leiðbeiningum tannlæknis. Tannáta er mesti áhættupátturinn í pessu tilfelli, benda má á eftirfarandi i pví samhengi $(2,3)$ :

$\checkmark$ Flúor-meðferð hjá tannlækni prisvar á ári

$\checkmark$ Skolun munns með Corsodyl munnskoli 7 daga í röð, í hverjum mánuði

$\checkmark$ Tannburstun tvisvar á dag með tannkremi með auknu flúor-innihaldi

$\checkmark$ Tyggigúmmí með Xylitol tvisvar á dag í a.m.k. 15 mín í senn

$\checkmark$ Vatnsdrykkja oft á dag

$\checkmark$ Neyslu einfaldra kolvetna stillt í hóf

Fræðsla og hvatning góðrar munnhirðu ætti að fara fram við hvert tækifæri hjá tannlækni.

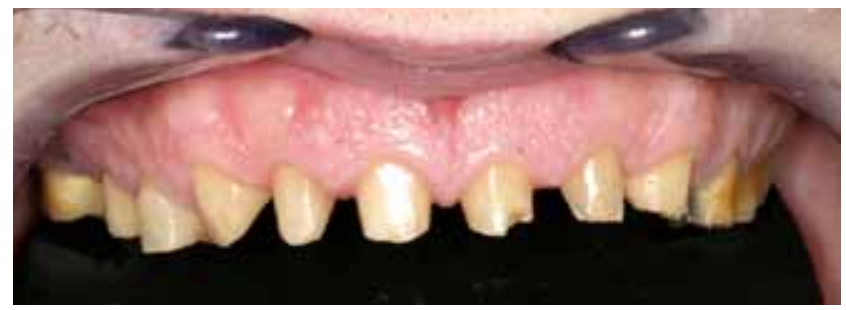

Mynd 13 - Framtennur við upphaf meðferðar

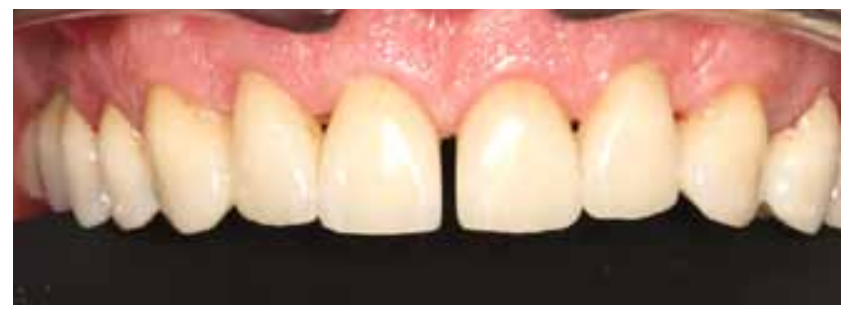

Mynd 14 - Framtennur við lok meðferðar

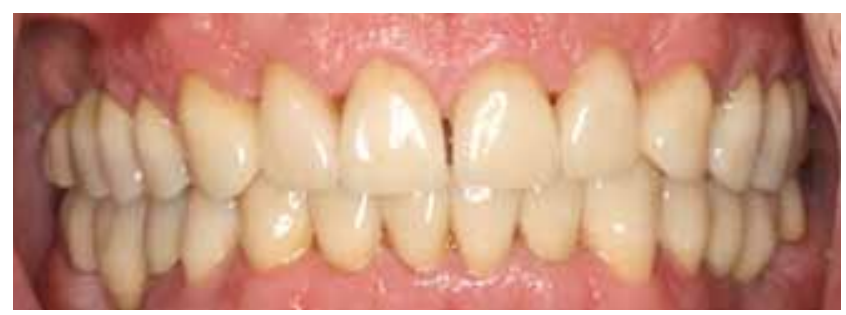

Mynd 15 - Frontal mynd eftir meðferð 


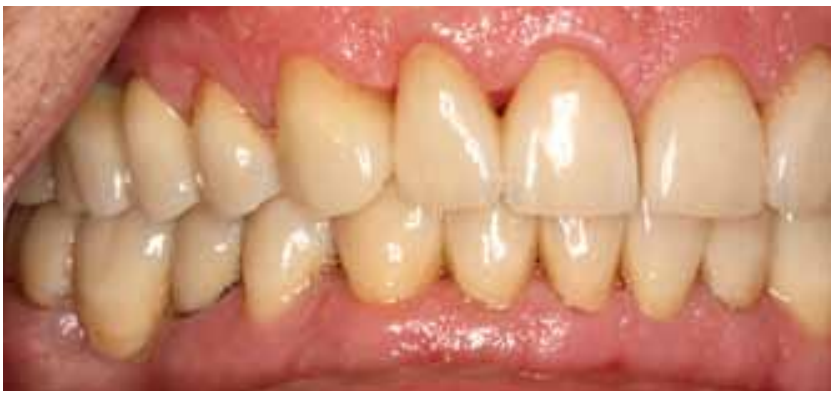

Mynd 16 - Hliðarmynd af vinstri hlið eftir meðferð

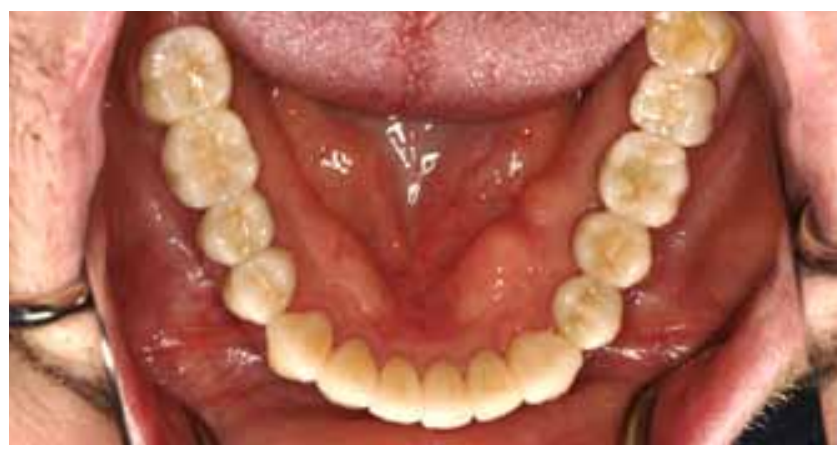

Mynd 17 - Occlusalmynd af neðri góm eftir meðferð

\section{Umræða}

Ekki er ljóst hversu mikið tannslitið var hjá sjúklingi fyrir meðferð erlendis og pví erfitt að fullyrða hvort virkileg pörf var á tanngervameðferð á öllum tönnum. Ofmeðhöndlun kemur vel til greina, par sem greining og undirbúningur var ekki réttur. Fyrir okkur, var ekki um annað аð ræða en endurreisa útlit, tyggigetu og bæta líðan sjúklings með ofangreindri meðferð.

pað er tæknilega flókið að krýna allar tennur munnsins í einu, bæði fyrir tannlækni og tannsmið. pví var ákveðið að

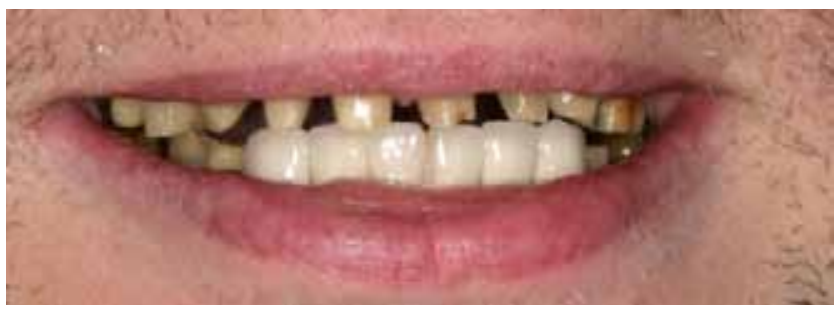

Mynd 18 - Brosmynd við upphaf meðferðar

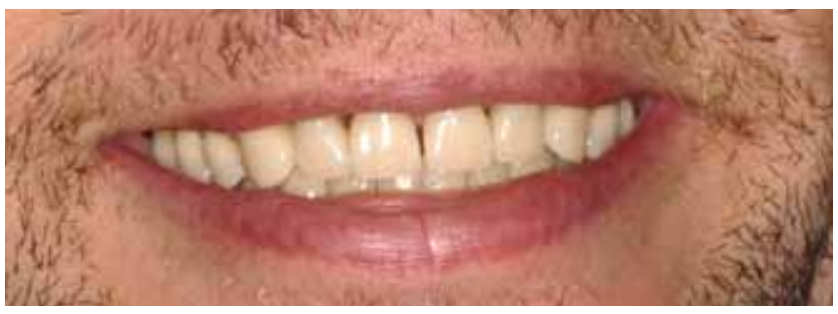

Mynd 19 - Hliðarmynd af vinstri hlið eftir meðferð

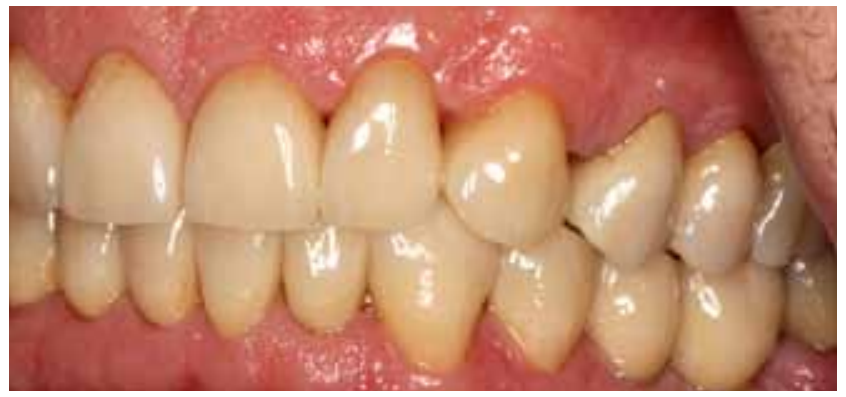

Mynd 20 - Hliðarmynd af hægri hlið eftir meðferð

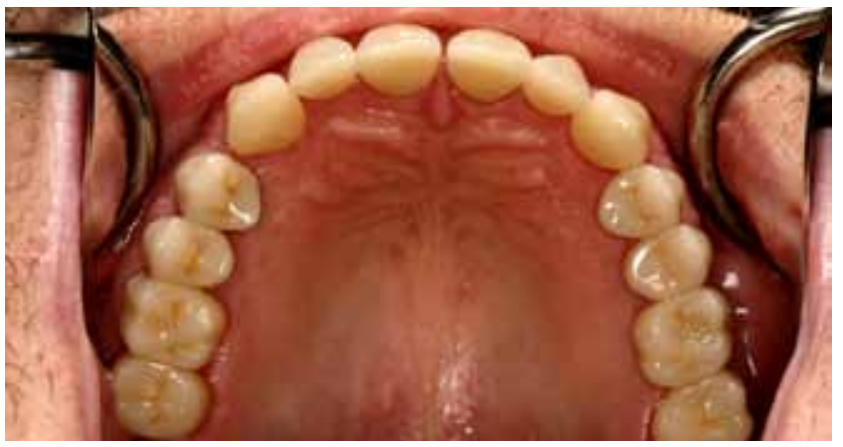

Mynd 21 - Occlusalmynd af efri góm eftir meðferð

gera verkið í tveimur áföngum, að ljúka efri gómi fyrst, vegna pess að hann skiptir útlislega meira máli.

Ýktur tannskurður var til staðar á framtönnum efri góms og óljós slípimörk. Til að auka hald og stöðugleika framtannakróna var ákveðið að notast við lithium disilicate postulín sem hægt er að sýruæta og líma með sjálfhertu og ljóshertu lími. Ekki var talin pörf á slíku á öðrum tönnum og pví zirconium postulín valið. Tæknilega er einfaldara að vinna með zirconium og pað er sterkara en lithium disilicate postulín pegar pláss er takmarkað og króna verður punn. Nánast engin ákveðin slípimörk voru greinanleg á brúnum við komu sjúklings. Vegna takmarkaðs tannvefs var tannskurði haldið í lágmarki par sem talin var pörf og fjaðurbrúnir urðu raunin $(4,5)$.

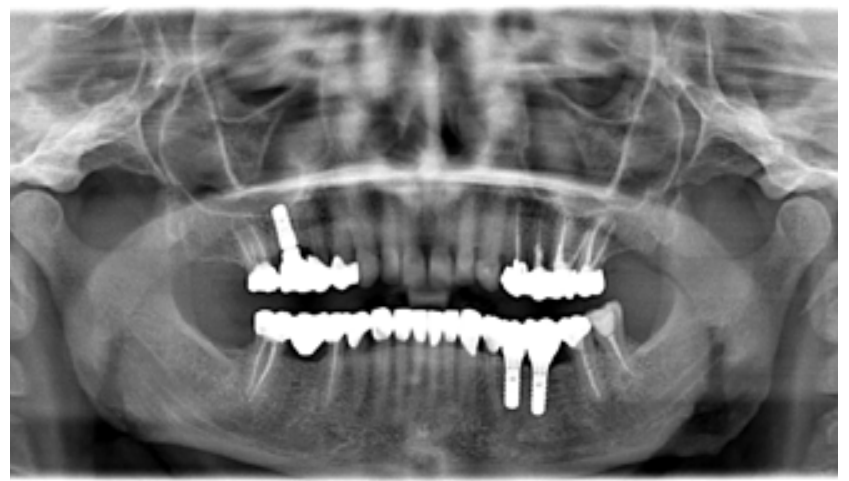

Mynd 22 - Breiðmynd við lok meðferðar 
Sjúklingum með Sjögren's hefur gengið vel með tannplantalausnir og tíðni tapaðra planta er lág. Peir Sjögren's sjúklingar sem hafa fengið tannplantastudd munn- og tanngervi telja lífsgæði sín hafa aukist umtalsvert (6).

Sérstakar pakkir fær Margrét Dan Pórisdóttir, tannsmiður sem vann verkið í samstarfi við Tannlæknadeild Háskóla Íslands.
Heimildir

1. Mathews SA, Kurien BT, Scofield RH. Oral manifestations of Sjögren's syndrome. Journal of dental research. 2008;87(4):308-18.

2. Featherstone JD, Singh S, Curtis DA. Caries risk assessment and management for the prosthodontic patient. J Prosthodont. 2011;20(1):2-9.

3. Featherstone JDB, Chaffee BW. The Evidence for Caries Management by Risk Assessment (CAMBRA®). Adv Dent Res. 2018;29(1):9-14.

4. Loi I, Di Felice A. Biologically oriented preparation technique (BOPT): a new approach for prosthetic restoration of periodontically healthy teeth. Eur J Esthet Dent. 2013;8(1):10-23.

5. Schweikert EO. Feather-edged or knife-edged preparation and impression technique. The Journal of prosthetic dentistry. 1984;52(2):243-6.

6. Chrcanovic BR, Kisch J, Wennerberg A. Dental implants in patients with Sjögren's syndrome: a case series and a systematic review. Int J Oral Maxillofac Surg. 2019;48(9):1250-9.

\title{
English Summary
}

\section{Case report: Retreatment from Eastern-Europe}

\author{
CAMILLA PETRA SIGURĐARDÓTTIR, DDS \\ ERNA R. EINARSDOTTIR, DDS, MS, ASSISTANT PROFESSOR, PROSTHODONTICS, FACULTY OF ODONTOLOGY, \\ UNIVERSITY OF ICELAND
}

ICELANDIC DENTAL JOURNAL 2020; 38: 40-45

doi: 10.33112/tann.38.1.4

This article is case report describing a treatment in an undergraduate dental clinic at The University of Iceland. The patient underwent a full mouth rehabilitation treatment abroad with fixed dental prostheses in 2011. Complications from treatment began shortly after delivery of the definitive prostheses. When the patient presented to our clinic in 2018 most of the prostheses had decemented. He suffered from teeth sensitivity due to his condition. The following treatment was done: Endodontic, restorative, and implants were inserted replacing missing teeth. Tooth preparations were adjusted, and the occlusal vertical dimension (OVD) re-established with carefully designed provisional restorations. Definitive prostheses were delivered at the determined OVD. The patient obtained proper oral function and esthetics and was relieved of his pain and sensitivity.

Keywords: fixed dental prostheses, occlusal vertical dimension, Sjogren's syndrome, caries risk assessment, feather-edge preparations. Correspondence: Camilla Petra Sigurðardóttir e-mail: camillapsig@gmail.com 